DOI: $10.4274 /$ tod. 75537

Turk J Osteoporos 2016;22:17-23

\title{
The Relationship of Osteoporosis Risk Factors with Bone Mineral Density in Patients Admitted Our Outpatient Clinic in Trabzon
}

\author{
Trabzon'da Ayaktan Poliklinik Merkezimize Başvuran Hastalarda Kemik Mineral \\ Yoğunluğu ile Osteoporoz Risk Faktörleri Arasındaki ilişski
}

\begin{abstract}
Münevver Serdaroğlu Beyazal, Erhan Çapkın*, Murat Karkucak*, Mustafa Güler**, Haşim Çakırbay***, Mehmet Tosun****

Recep Tayyip Erdoğan University Faculty of Medicine, Department of Physical Medicine and Rehabilitation, Rize, Turkey *Karadeniz Tecnical University Faculty of Medicine, Department of Physical Medicine and Rehabilitation, Trabzon, Turkey

**Bezmialem Vakıf University Medical Hospital, Clinic of Physical Medicine and Rehabilitation, Istanbul, Turkey ***Turgut Özal University Faculty of Medicine, Department of Physical Medicine and Rehabilitation, Ankara, Turkey ****Fizyotem, Physical Medicine and Rehabilitation Center, Trabzon, Turkey
\end{abstract}

\section{Summary}

Objective: Our aim was to identify the relationship of osteoporosis (OP) risk factors with bone mineral density (BMD) in patients admitted our outpatient clinic in Trabzon.

Materials and Methods: Two hundred one patients with OP or osteopenia were included in this study. Sociodemographic characteristics of the patients were recorded and a standardized interview was employed by the researcher physician. BMD values were measured by dual energy X-ray absorptiometry at lumbar spine and femoral neck.

Results: The mean age of the patients was $61.47 \pm 10.57$ years (182 females/19 males). One hundred fifteen patients (57.2\%) were osteoporotic and 86 (42.8\%) were osteopenic. A significant negative correlation was found between age and femoral neck $T$ scores. The number of pregnancies showed a significant negative correlation with lumbar T scores. Body mass index and daily tea consumption showed a negligible positive correlation with femoral neck T scores. No association was found between age at menarche, age at menopause, total lactation duration, daily calcium intake and T scores of lumbar spine and femoral neck.

Conclusions: Identification of regional OP risk factors may be useful for the OP risk management of patients in clinical practice.

Keywords: Osteoporosis, risk factors, bone mineral density

\section{Öz}

Amaç: Bu çalışmada amacımız Trabzon ilinde ayakta tedavi kliniğine başvuran hastalarda osteoporoz (OP) risk faktörlerinin kemik mineral yoğunluğu (KMY) ile ilişkisini belirlemektir.

Gereç ve Yöntem: Çalışmaya OP veya osteopeni tanılı 201 hasta dahil edildi. Hastaların sosyodemografik özellikleri kaydedildi ve standardize araştırma formu araştırmacı hekim tarafından dolduruldu. KMY ölçümleri dual enerji X-ray taraması ile lomber omurga ve femur boynundan yapıldı.

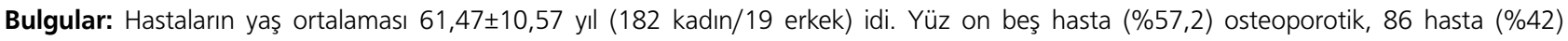
osteopenikti. Yaş ile femoral T skorları arasında negatif yönde anlamlı korelasyon bulundu. Gebelik sayısı lomber T skorları ile negatif yönde anlamlı korelasyon gösterdi. Vücut kitle indeksi ve günlük çay tüketimi ile femoral T skorları arasında inmal edilebilir pozitif yönde korelasyon tespit edildi. Menarş yaşı, menopoz yaşı, toplam laktasyon süresi, ve günlük kalsiyum tüketimi ile KMY arasında herhangi bir korelasyon bulunmadı.

Sonuç: OP için yöresel risk faktörlerinin tanımlanması klinik uygulamalarda hastaların OP risk yönetimine faydalı olabilir.

Anahtar kelimeler: Osteoporoz, risk faktörleri, kemik mineral yoğunluğu 


\section{Introduction}

Osteoporosis (OP) is a systemic skeletal disease characterized by low bone mass and microarchitectural deterioration of the bone tissue, with consequent increase in bone fragility and susceptibility to fracture (1). It affects approximately 200 millions of people worldwide and happens to be the most common metabolic skeletal disease. OP became one of the most important health problems due to its increasing mortality, morbidity, and socio-economical effects as a result of the prolongation of life.

Bone mineral density (BMD) peaks at around the age of 35 and thereafter declines in both men and women with bone loss being particularly marked in postmenopausal women. Hence, measures to prevent OP should be aimed at both maximizing the peak bone density at skeletal maturity and at retarding the subsequent bone loss. Various risk factors in OP have been reported including physical activity, body mass profile, menopausal status, alcohol, smoking, corticosteroids, caffeine and high protein, salt or phosphorus intake (2).

The fracture risk assessment (FRAX) is a fracture assessment tool developed by the World Health Organization (WHO) (3). FRAX allows clinicians to calculate a patient's 10-year absolute risk for hip or "any major" fracture (including fractures of the hip, wrist, humerus, or spine). It has been shown to have at least $13 \%$ higher discrimination for predicting the possible future fractures in women compared to BMD alone. Probability is calculated from age, body mass index (BMI), and dichotomized risk factors comprising prior fragility fracture, parenteral history of hip fracture, current tobacco smoking, long-term oral glucocorticoid use, rheumatoid arthritis, other causes of secondary OP and excessive alcohol consumption (4). Individuals at high risk for OP and osteoporotic fractures may be identified by determination of the risk factors. Thus, fractures may be prevented through modification of the risk factors. Our aims were to identify the prevalence of OP risk factors in patients admitted our outpatient clinic in Trabzon and to detect association of these risk factors with BMD in this population.

\section{Materials and Methods}

This cross-sectional study was conducted between July 2006 and June 2007. The study was approved by the local ethics committee, and each patient provided their written informed consent prior to participation. This study was performed in accordance with the principles stated in Declaration of Helsinki. Two hundred one consecutive patients with OP or osteopenia who were referred to our OP outpatient clinic for diagnosis or treatment were included in this study. Patients previously treated for OP and/or had significant vertebral deformity were excluded from the study as these conditions might affect the dual energy X-ray absorptiometry (DXA) measurements.

Using DXA (Hologic Q 2000), BMD measurements were taken at both of the lumbar spine (L1-4) and left femoral neck. WHO classification ranges were used to categorize subjects as normal $(T>-1)$, osteopenic $(-2.5<T \leq-1)$, or osteoporotic ( $T \leq-$ 2.5) (5). Questionnaire included information about educational status, occupation, age, height, weight, personal and maternal fracture history, age at menarche and menopause, reproductive period characteristics, chronic diseases, physical activity, smoking status, dietary calcium intake, tea, alchol and caffeine consumption which were obtained by an intervieweradministered questionnaire. Height and weight were measured and BMI was calculated by dividing weight in kilograms by height in meters squared. We calculated daily calcium intake by estimation of the number of servings patient have on a typical day for each type of food including milk (300 cc), yoghurt (250 $\mathrm{cc}$ ), and cheese (1 cubic inch). Calculation of total daily calcium intake was performed according to local food composition tables. After we have calculated the amount of calcium for each dairy product, $250 \mathrm{mg}$ of calcium was added to the estimated amount of calcium each day from other foods. A low dietary calcium intake threshold of $300 \mathrm{mg}$ was used in the present study. This cut-off value is equal to one quarter of the daily calcium allowance recommended for persons aged 50 years and older by the National Academy of Science (6). The daily tea consumption was classified as drinking 1 cup/day, 2-3 cups/day, 4-5 cups/day and 6 or more cups/day ( 1 cup=237 $\mathrm{mL})$. Cigarette smoking was divided into never, former, and current categories based on the responses to the questions. Never-smokers were defined as those who had not smoked 100 cigarettes in their entire life, while former-smokers were defined as those who had smoked 100 cigarettes in their life but who did not smoke currently. Ever-smokers were defined as either former- or current-smokers. The participants were classified in terms of their reported current and lifelong caffeine consumption into the following groups; (i) none; (ii) low, equivalent to none to one cup of caffeinated coffee per day; and (iii) high, equivalent to two or more cups of caffeinated coffee per day.

Statistical analysis was performed using the Statistical Package for the Social Sciences (SPSS), version 11.5, for Windows (SPSS, Chicago, IL, USA). Data obtained by measurement was presented in arithmetic average \pm standard deviation and data obtained by count was presented in percentages (\%). For all tests, a $p<0.05$ was used to indicate a statistical significance. The relationship of identified risk factors for OP such as age, $\mathrm{BMI}$, age at menarche, age at menopause, total lactation period, the number of pregnancies, and dietary habits with $\mathrm{BMD}$ was tested with Pearson correlation analysis.

\section{Results}

The main characteristics of patients who participated in the study are summarized in Table 1. Of the patients included in this study, $90.5 \%$ were females, and the mean age of the study population was $61.47 \pm 10.57$ years. Educational attainment of the sample was quite varied; $85.6 \%$ had less than a high school diploma. The mean BMI was $27.00 \pm 4.51 \mathrm{~kg} / \mathrm{m}^{2}$. Female 
patients' mean age at menarche, age at menopause, number of pregnancies, and number of children were $13.93 \pm 1.44$ years, $44.67 \pm 5.92$ years, $4.95 \pm 2.86,3.66 \pm 2.03$, respectively. Total lactation duration was determined as $43.90 \pm 38.76$ months. Eleven women (6\%) reported using hormone replacement therapy (HRT).

Among participants, 174 (86.6\%) never-smoker in their lives while $15(7.5 \%)$ were former-smoker and 12 (6\%) currentsmoker.

The questionnaire revealed that $29.4 \%$ of the patients performed a half hour sports activity at least three days of a week while $70.6 \%$ did not perform any sports activities.

The mean daily tea consumption was $2.43 \pm 1.61$ cups/day. Among 201 participants, 6 (3\%) patients did not drink tea daily, 58 (28.9\%) drank one cup per day, 103 (51.2\%) drank 2-3 cups per day, 26 (12.9\%) drank 4-5 cups, and 8 (4\%) drank 6 or more cups of tea per day. The mean daily calcium intake value was $399.1 \pm 160.2 \mathrm{mg}$ and in $145(72.1 \%)$ of the all participants had a low dietary calcium intake threshold of $300 \mathrm{mg}$.

Fifteen patients $(7.7 \%)$ had fracture history occurred over 40 years of age with spontaneous or minimal trauma and these fractures consisted of $11(73.3 \%)$ forearm fractures and 4 (26.7\%) vertebral fractures. According to the evaluation of maternal fracture history, $17(8.5 \%)$ had a fracture history in their mothers.

Ninety nine patients (49.3\%) had chronic diseases. Chronic diseases consisted of hypertension (30.8\%), diabetes mellitus
$(5.5 \%)$, goiter $(4 \%)$, rheumatic diseases $(2.5 \%)$, and others (6.5\%).

One hundred fifteen patients (57.2\%) were diagnosed with $\mathrm{OP}$ and $86(42.8 \%)$ patients were diagnosed with osteopenia according to the BMD values obtained from L1-L4 vertebrae. According to the BMD values obtained from femoral neck, $38.3 \%$ of patients were diagnosed with OP while $61.7 \%$ of patients were diagnosed with osteopenia. The mean BMD was $-2.64 \pm 0.82$ based on measurements at lumbar spine and $-2.22 \pm 0.87$ based on measurement obtained from femoral neck. Relationship between BMD and probable risk factors are summarized in Table 2. There was no correlation between age at menarche, age at menopause, total lactation duration, daily calcium intake and BMD values of lumbar and femoral neck. A significant negative correlation was observed between age and BMD values for lumbar and femoral neck (respectively, $r=-0.186, p=0.008 ; r=-0.248, p=0.001$ ). There was a significant negative correlation between the number of pregnancies and the BMD values for lumbar $(r=-0.200, p=0.007)$, but there was no correlation for the femoral neck $(r=-0.045, p=0.147)$. A negligible correlation was observed between $\mathrm{BMI}$ and femoral $\operatorname{BMD}(r=0.169, p=0.016)$, whereas there was no correlation between BMI and lumbar BMD ( $r=0.017, p=0.807)$. There was a negligible correlation between BMD values and daily tea consumption for femoral neck $(r=0.178, p=0.013)$, but there was no correlation for lumbar spine BMD ( $r=0.109, p=0.130)$.

\section{Table 1. Demographic and clinical characteristics of participants}

\begin{tabular}{|c|c|}
\hline Age, mean $\pm S D$, years & $61.47 \pm 10.57$ \\
\hline Education $>12$ years $[\mathrm{n}(\%)]$ & $29(14.4)$ \\
\hline Male gender [n (\%)] & $19(9.5)$ \\
\hline Female gender [n (\%)] & $182(90.5)$ \\
\hline $\mathrm{BMI}$, mean $\pm \mathrm{SD}\left(\mathrm{kg} / \mathrm{m}^{2}\right)$ & $27.0 \pm 4.5$ \\
\hline Age at menarche (years) & $13.9 \pm 1.4$ \\
\hline Age at menopause (years) & $44.6 \pm 5.9$ \\
\hline Duration of lactation (month) & $43.9 \pm 38.8$ \\
\hline Fragility fracture in mother [n (\%)] & $17(8.5)$ \\
\hline Prevalent fragility fracture after 40 years [n (\%)] & $15(7.7)$ \\
\hline HRT use $[n(\%)]$ & $11(6)$ \\
\hline Moderate daily phsysical activity [n (\%)] & $59(29.4)$ \\
\hline Daily calcium intake, mean \pm SD, mg & $399.1 \pm 160.2$ \\
\hline Inefficient calcium intake & $145(72.1)$ \\
\hline Daily tea consumption (cups/day) & $2.4 \pm 1.6$ \\
\hline Osteoporosis (Lumbar spine) n (\%) & $115(57.2)$ \\
\hline Osteoporosis (femoral neck) n (\%) & $77(38.3)$ \\
\hline \multicolumn{2}{|l|}{ Bone mineral density by DXA, mean (SD) } \\
\hline L1-4 T scores & $-2.64 \pm 0.82$ \\
\hline Femoral neck T scores & $-2.22 \pm 0.87$ \\
\hline Trochanter T scores & $-2.10 \pm 0.81$ \\
\hline
\end{tabular}


Table 2. Various parameters and their relationship with bone mineral density in lumbar and femoral region

\begin{tabular}{|l|l|l|l|}
\hline & Mean \pm SD & Lumbar T score & Femoral neck T score \\
\hline Age (years) & $61.5 \pm 10.6$ & $\begin{array}{l}r=-0.186 \\
p=0.008\end{array}$ & $\begin{array}{l}r=-0.284 \\
p=0.001<\end{array}$ \\
\hline BMI $\left(\mathrm{kg} / \mathrm{m}^{2}\right)$ & $27.0 \pm 4.5$ & $\begin{array}{l}r=0.017 \\
p=0.807\end{array}$ & $p=0.016$ \\
\hline Age at menarche (years) & $13.9 \pm 1.4$ & $\begin{array}{l}r=-0.143 \\
p=0.772\end{array}$ & $\begin{array}{l}r=-0.09 \\
p=0.207\end{array}$ \\
\hline Age at menopause (years) & $44.6 \pm 5.9$ & $\begin{array}{l}r=0.022 \\
p=0.772\end{array}$ & $\begin{array}{l}r=0.045 \\
p=0.552\end{array}$ \\
\hline Number of pregnancies (n) & $4.9 \pm 2.8$ & $\begin{array}{l}r=-0.200 \\
p=0.007\end{array}$ & $\begin{array}{l}r=-0.045 \\
p=0.147\end{array}$ \\
\hline Lactation duration (months) & $43.9 \pm 38.7$ & $\begin{array}{l}r=-0.139 \\
p=0.062\end{array}$ & $p=0.107$ \\
\hline Daily calcium intake (mg/day) & & $\begin{array}{l}r=0.003 \\
p=0.970\end{array}$ & $\begin{array}{l}r=0.062 \\
p=0.385\end{array}$ \\
\hline Daily tea consumption (cup/day) & $399.1 \pm 160.2$ & $\begin{array}{l}r=0.109 \\
p=0.130\end{array}$ & $\begin{array}{l}r=0.178 \\
p=0.013\end{array}$ \\
\hline SD: Standard deviation, BMD: Bone mineral density, BMI: Body mass index & $2.4 \pm 1.6$ & & \\
\hline
\end{tabular}

\section{Discussion}

Although OP is a concern for an entire population, it is most commonly observed in postmenopausal women. The medical and social consequences of the fracture make OP an important public health problem. There is a vast increase in one or more osteoporotic fractures in $40 \%$ of women and $13 \%$ of men throughout of their lives after 50 years of age. About $20 \%$ of women and $40 \%$ of men die within one year after hip fracture. It has been estimated that $50 \%$ of women who sustain a hip fracture become functionally dependent in their daily activities, and $19 \%$ require long-term nursing home care because of the fracture (7). In FRACTURK study, it has been reported that, for 50-year-old Turkish women, about one of every seven will sustain a hip fracture during their remaining lifetime (4). In this study, the authors also demonstrated a significant increase of hip fracture incidence with age and that more than 24.000 hip fractures occurred annually in men and women aged 50 years or more in 2010.

$\mathrm{OP}$ is a clinical condition occurring via combined effects of many risk factors. Peak bone mass which is occurred by genetic potential can also be modified with other factors like nutrition, exercise, and hormonal status. One obvious approach is the promotion of beneficial factors and discouragement of risk factors in the general population. Another approach is the identification of individuals at high-risk. In many longitudinal prospective studies, a relationship between BMD and age, age at menopause, duration of menopause, weight, daily calcium intake, alcohol consumption, smoking, exercise habits, and history of fractures has been shown (8-10).

In this study, the vast majority of the cases were women with a mean age was $61.3 \pm 10.2$ years. A negative correlation was observed between age and the BMD values for both femoral neck and lumbar spine. The negative qualitative changes associated with aging primarily affect women. Bone turnover, bone formation rate, osteoid volume and thickness are high in men compared with women (11). Whereas the decrease in bone mass by aging is $0.05-1 \%$ annually, within ten years after menopause this ratio reaches $3-6 \%$ in women (12). In the Os des Femmes de Lyon (OFELY) study, 672 healthy postmenopausal women were included and it was reported that age can predict the risk of fragility fractures in postmenopausal women independently of the level of BMD (13).

The fracture risk is higher in women with lower body weight compared to those with normal or higher body weight and similarly those being over their normal weight status are rarely affected by OP. The reasons for this are strengthening of the bones with increasing weight and protection from OP provided with estrogen metabolites produced by fat cells (14). In this study, a negligible correlation was determined between $\mathrm{BMI}$ and $\mathrm{BMD}$ values for femoral neck region, but no statistically significant correlation was observed for lumbar region. In a cross-sectional case-control study including 537 postmenopausal women, it was shown that BMI correlated positively with femoral neck and lumbar spine BMD (15). In the community-based study analysis [National Health and Nutrition Examination Survey (NHANES III) in which 2.590 women and 2.391 men between 50-79 years of age were included, the most important and statistically significant risk factors identified were low BMI, low calcium intake, current cigarette smoking, and physical inactivity (16). As reported in former studies, low $\mathrm{BMI}$ was shown to be the strongest modifiable determinant of low BMD in women and men aged 50-79 years also in this study $(17,18)$.

In this study, fracture history was present in $7.7 \%$ of the cases and $73 \%$ of these fractures were in the forearm and $26.7 \%$ of them were vertebral fractures. There was maternal fracture history in $8.5 \%$ of the participants. In OFELY study, history 
of postmenopausal maternal fracture was identified as one of the predictors of fracture independent from other factors (13). Similarly, in the Study of Osteoporotic Fractures, the most comprehensive study of risk factors in American population including 9.516 women 65 years of age and older, maternal hip fracture was shown to be one of the 14 clinical risk factors identified as significant predictors of hip fracture in multivariable models (19). Any fracture since 50 years of age also identified as clinical risk factors in this study. In a large cohort, a total of 7.512 women older than 75 years which were followed for an average of 3.9 years in the prospective epidemiology of OP study. This study revealed that fracture history since the age of 40 years was one of the most valuable predictors of hip fracture (20).

Although in some studies delayed menarche, premature menopause, and short reproductive period were reported as possible risk factors, other studies found no association (21-25). While no significant correlation was present between BMD and age at menarche, age at menopause, and lactation period in our study, a small but significant negative correlation was observed between lumbar BMD and number of pregnancies. Hassa et al. (26) found no significant relationship between BMD and age at menopause, age at menarche, and number of pregnancies ( $p>0.05$, for all). In the study of Li and Zhu (27), OP was observed to be more common with older menarche age and premature menopause, and longer lactation period and higher number of pregnancies were found to be related to low BMD.

During lactation, prolactin inhibits estrogen and induces parathyroid hormone-related protein (PTHrP) synthesis. Because of the combined effects of PTHrP synthesis and estrogen insufficiency, skeletal resorption increases, the blood calcium raises, PTH levels suppress during this period, but urinary calcium excretion decreases and calcium passes to breast milk (28). It was demonstrated that there was a significant relationship between the total lactation period and the lumbar and femoral BMD in a study included 1.486 post-menapausal women by Dursun et al. (29). Moreover, they reported that lumbar and femoral neck BMD of female patients with longer lactation periods were lower than those of female patients with shorter lactation periods. Similar results were also demonstrated in other studies $(30,31)$

In the light of the available data, the relationship between pregnancy and bone mass is complicated and it still remains unclear. Theoretically, bone mass may decrease during pregnancy because of the requirement of calcium during pregnancy. On the contrary, bone mass may increase due to more estrogen exposure in the third trimester and increased weight enforcement of bones throughout the pregnancy (32). A positive relationship between the number of pregnancies and the femoral BMD was reported in postmenopausal women by Melton et al. (33) and a positive association with parity in the femoral and lumbar BMD of premenopausal women was observed by Laitinen et al. (34). In contrast, Gür et al.
(32) revealed a negative correlation between the number of pregnancies and BMD values for spine, trochanter, and Ward's triangle with no significant correlation for femoral neck BMD. Heidari et al. (15) have also demonstrated that parity was associated with increased risk of OP in the elderly postmenopausal women. On the other hand, it has been reported that no relationship existed between pregnancy and bone mass in another studies (35-37). In this study, a negative correlation between the number of pregnancies and BMD values for lumbar vertebrae was identified, but there was no correlation for the femoral neck BMD.

Tea is widely consumed all over the world and may affect BMD through several distinct mechanisms. It is one of the main sources of phytoestrogen and fluoride which may be beneficial for BMD. Fluoride is a very potent and highly bonespecific anabolic substance. On the other hand, types of teas except the ones with herbal nature contain significant amount of caffeine, which may result in the loss of BMD. A study conducted in United States with 50-60 years aged prepostmenopausal women revealed that there was an inverse relationship between tea consumption and BMD (38). In contrast, a positive association with tea consumption in BMD was reported among postmenopausal women in Canada, in the United Kingdom, and adult women and men in Asia (3941). Moreover, in the Mediterranean Osteoporosis study, it was demonstrated that tea consumption was related to $30 \%$ reduction in the risk of hip fractures in both women and men $(42,43)$. In this study, there was no relationship between the tea consumption and the lumbar BMD whereas a negligible positive association with tea consumption in the femoral neck BMD. Association of femoral neck T scores with tea and coffee consumption was demonstrated in another study (44).

Nutrition is an important factor for the continuation of bone quality in OP (45). The nutrition is also included in the training programs of health services besides the prevention of bone fragility in elderly people and postmenopausal women, the determination of risk groups and the protection from falling. In this study, the mean daily calcium intake of participants was $399.12 \pm 160.2 \mathrm{mg} / \mathrm{d}$ and none of the patients had $1200 \mathrm{mg} / \mathrm{d}$ intake which is the amount that should have been normally taken. There was no relationship between the daily calcium intake and BMD. Despite the data that calcium supplementation has been helpful in order to prevent bone mass loss in randomized controlled clinical trials $(46,47)$, the relationship between the dietary calcium intake and the BMD still remains unclear (16). However, inadequate dietary calcium intake was found to be related with low BMD in cross-sectional studies (48-50).

\section{Conclusion}

our study found that lumbar $\mathrm{T}$ scores showed a negative correlation with number of pregnancies, whereas femoral $T$ scores have a negative correlation with age, and a negligible 
correlation with $\mathrm{BMI}$ and tea consumption. No significant relationship between age at menarche, age at menopause, total lactation duration, daily calcium intake and BMD was demonstrated. Identification of regional OP risk factors may be useful for the OP risk management of patients in clinical practice. However, further large sample follow-up studies are required to describe precise regional risk factors for OP.

\section{Ethics}

Ethics Committee Approval: Karadeniz Technical University Ethics Committee, Informed Consent: It was taken.

Peer-review: Internal peer-reviewed.

\section{Authorship Contributions}

Concept: Mustafa Güler, Design: Murat Karkucak, Münevver Serdaroğlu Beyazal, Data Collection or Processing: Münevver Serdaroğlu Beyazal, Analysis or Interpretation: Münevver Serdaroğlu Beyazal, Erhan Çapkın, Murat Karkucak, Mustafa Güler, Haşim Çakırbay, Mehmet Tosun, Literature Search: Münevver Serdaroğlu Beyazal, Writing: Münevver Serdaroğlu Beyazal.

Conflict of Interest: No conflict of interest was declared by the authors.

Financial Disclosure: The authors declared that this study has received no financial support.

\section{References}

1. Consensus Development Conference: Diagnosis, prophylaxis and treatment of osteoporosis. Am J Med 1993;94:645-50.

2. Cohen AJ, Roe FJ. Review of risk factors for osteoporosis with particular reference to a possible aetiological role of dietary salt. Food Chem Toxicol 2000;38:237-53.

3. Unni S, Yao Y, Milne N, Gunning K, Curtis JR, LaFleur J. An evaluation of clinical risk factors for estimating fracture risk in postmenopausal osteoporosis using an electronic medical record database. Osteoporos Int 2015;26:581-7.

4. Tuzun S, Eskiyurt N, Akarırmak U, Sarıdoğan M, Senocak M, Johansson $\mathrm{H}$, et al. Incidence of hip fracture and prevalence of osteoporosis in Turkey: The FRACTURK study. Osteoporos Int 2012;23:949-55.

5. Kanis JA, Melton LJ, Christiansen C, Johnston CC, Khaltaev N. The diagnosis of osteoporosis. J Bone Miner Res 1994;9:1137-41.

6. Yates AA, Schlicker SA, Suitor CW. Dietary Reference Intakes: The new basis for recommendations for calcium and related nutrients, B vitamins, and choline. J Am Diet Assoc 1998;98:699-706.

7. Riggs BL, Melton LJ. The prevention and treatment of osteoporosis. N Engl J Med 1992;327:620-7.

8. Torgerson DJ, Campbell MK, Reid DM. Life style, environmental and medical factors influencing peak bone mass in women. $\mathrm{Br} J$ Rheumatol 1995;34:620-4.

9. Johnston CC Jr, Longcope C. Premenopausal bone loss-a risk factor for osteoporosis. N Eng J Med 1990;323:1271-3.

10. Kröger H, Tuppurainen M, Honkanen R, Alhava E, Saarikoski $\mathrm{S}$. Bone mineral density and risk factors for osteoporosis- a population based study of 1600 perimenopausal women. Calcif Tissue Int 1994;55:1-7.

11. Melson F, Mosekilde L. The role of bone biopsy in the diagnosis of metabolic bone disease. Orthop Clin North Am 1981;12:571-602.

12. Raisz LG. Local and systemic factors in pathogenesis of osteoporosis. N Eng J Med 1988;318:818-28.

13. Albrand G, Munoz F, Sornay-Rendu E, DuBoeuf F, Delmas PD. Independent predictors of all osteoporosis-related fractures in healthy postmenopausal women: The OFELY Study. Bone 2003;32:78-85.

14. Bartl R, Frisch B. Osteoporosis. Diagnosis, Prevention, Treatment. 1st edition: Springer-Verlag Berlin Heidelberg; 2004
15. Heidari B, Hosseini R, Javadian Y, Bijani A, Sateri MH, Nouroddini HG. Factors affecting bone mineral density in postmenopausal women. Arch Osteoporos 2015;10:15.

16. Broussard DL, Magnus JH. Risk assesment and screening for low bone mineral density in multi-ethnic population of women and men: Does one approach fit all? Osteoporos Int 2004;15:349-60.

17. Hannan MT, Felson DT, Dawson-Hughes B, Tucker KL, Cupples LA, Wilson PW, et al. Risk factors for longitudinal bone loss in elderly men and women: The Framingham Osteoporosis Study. J Bone Miner Res 2000;15:710-20.

18. Bendavid EJ, Shan J, Barrett-Connar E. Factors associated with bone mineral density in middle-aged men. J Bone Miner Res 1996;11:1185-90.

19. Cummings SR, Nevitt MC, Browner WS, Stone K, Fox KM, Ensrud $\mathrm{KE}$, et al. The study of osteoporotic fractures. Risk factors of hip fracture in white women. N Eng J Med 1995:332;767-73.

20. Dargent-Molina P, Piault S, Bréart G. A triage strategy based on clinical risk factors for selecting elderly women for treatment or bone densitometry: The EPIDOS prospective study. Osteoporos Int 2005;16:898-906.

21. Kritz-Silverstein D, Barrett-Connor E. Early menopause, number of reproductive years, and bone mineral density in postmenopausal women. Am J Public Health 1993;83:983-8.

22. Hu JF, Zhao XH, Chen JS, Fitzpatrick J, Parpia B, Campbell TC. Bone density and lifestyle characteristics in premenopausal and postmenopausal Chinese women. Osteoporos Int 1994;4:288-97.

23. Sowers MR, Clark MK, Hollis B, Wallace RB, Jannausch M. Radial bone mineral density in pre and perimenopausal women. J Bone Miner Res 1992;7:647-57.

24. Bagur AC, Mautalen CA. Risk for developing osteoporosis in untreated premature menopause. Calcif Tissue Int 1992;51:4-7.

25. Davies MC, Hall ML, Jacobs HS. Bone mineral loss in young women with amenorrhoea. BMJ 1990;301:790-3.

26. Hassa H, Tanir HM, Senses T, Oge T, Sahin-Mutlu F. Related factors in bone mineral density of lumbal and femur in natural postmenopausal women. Arc Gynecol Obstet 2005;273:86-9.

27. Li HL, Zhu HM. Relationship between age of menarghe, menopause and other factors and postmenopause osteoporosis. Zhonghua Fu Chan Ke Za Zhi 2005;40:796-8.

28. Kalkwarf HJ. Hormonal and dietary regulation of changes in bone density during lactation and after weaning in women. J Mammary Gland Biol Neoplasia 1999;4:319-29.

29. Dursun N, Akın S, Dursun E, Sade I, Korkusuz F. Influence of duration of total breast feeding on bone mineral density in a Turkish population: Does the priority of risk factors differ from society to society? Osteoporos Int 2006;17:651-5.

30. Yazici S, Korkmaz U, Erkan M, Korkmaz N, Erdem Baki A, Alçelik $A$, et al. The effect of breast-feeding duration on bone mineral density in postmenopausal Turkish women: A population based study. Arch Med Sci 2011;7:486-92.

31. Khoo CC, Woo J, Leung PC, Kwok A, Kwok T. Determinants of bone mineral density in older postmenopausal Chinese women. Climacteric 2011;14:378-83.

32. Gur A, Nas K, Cevik R, Sarac AJ, Ataoglu S, Karakoc M. Influence of number of pregnancies on bone mineral density in postmenopausal women of different age groups. J Bone Miner Metab 2003;21:234-41.

33. Melton LJ, Bryant SC, Wahner HW, O'Fallon WM, Malkasian GD, Judd $\mathrm{HL}$, et al. Influence of breastfeeding and other reproductive factors on bone mass later in life. Osteoporosis Int 1993;3:7683.

34. Laitinen $K$, Välimäki $M$, Keto $P$. Bone mineral density measured by dual energy X-ray absorptiometry in healthy Finnish women. Calcif Tissue Int 1991;48:224-31.

35. Sioka C, Fotopoulos A, Georgiou A, Xourgia X, Papadopoulos A, Kalef-Ezra JA. Age at menarche, age at menopause and duration of fertility as risk factors for osteoporosis. Climacteric 2010;13:6371.

36. Uzun Ö, Köklü K, Özel S, Yılmaz Şahin A, Ünsal Delialioğlu S, Kulaklı F. Evaluation of gynecological risk factors in osteoporosis. Acta Oncol Tur 2014;47:11-5. 
37. Bauer DC, Browner WS, Cauley JA, Orwoll ES, Scott JC, Black DM et al. Factors associated with appendicular bone mass in older women. Ann Intern Med 1993;118:657-65.

38. Hernández-Avila $M$, Stampfer MJ, Ravnikar VA, Willett WC, Schiff I, Francis M, et al. Caffeine and other predictors of bone density among pre- and perimenopausal women. Epidemiology 1993;4:128-34.

39. Hoover PA, Webber CE, Beaumont LF, Blake JM. Postmenopausal bone mineral density: Relationship to calcium intake, calcium absorption, residual estrogen, body composition and physical activity. Can J Physiol Pharmacol 1996;74:911-7.

40. Hegarty VM, May HM, Khaw KT. Tea drinking and bone mineral density in older women. Am J Clin Nutr 2000;71:1003-7.

41. Wu CH, Yang YC, Yao WJ, Lu FH, Wu JS, Chang CJ. Epidemiological evidence of increased bone mineral density in habitual tea drinkers. Arch Intern Med 2002;162:1001-6.

42. Johnell O, Gullberg B, Kanis JA, Allander E, Elffors L, Dequeker J, et al. Risk factor for hip fracture in European women: The MEDOS Study. Mediterranean Osteoporosis Study. J Bone Miner Res 1995;10:1802-15.

43. Kanis J, Johnell O, Gullberg B, Allander E, Elffors L, Ranstam J, et al. Risk factors for hip fractures in men from southern Europe: The MEDOS Study. Mediterranean Osteoporosis Study. Osteoporos Int 1999;9:45-54.
44. Umay E, Tamkan U, Gündoğdu i, Umay S, Çakcı A. The effect of osteoporosis risk factors on bone mineral density. Turk J Osteoporos 2011;17:44-50.

45. Eaton-Evans J. Osteoporosis and the role of diet. Br J Biomed Sci 1994;5:358-70.

46. Dawson-Hughes B, Harris SS, Krall EA, Dallal GE. Effect of calcium and vitamin $\mathrm{D}$ supplementation on bone density in men and women 65 years old age or older. N Engl J Med 1997;337:670-6.

47. Riggs BL, O'Fallon WM, Muhs J, O'Connor MK, Kumar R, Melton LJ. Long term effects of calcium supplementation on serum parathyroid hormone level, bone turnover and bone loss in elderly women. J Bone Miner Res 1998;13:168-74.

48. Özdemir F, Demirbağ Kabayel D, Türe M. Do dietary Calcium Intake and Hormone Replacement Therapy Affect Bone Mineral Density in Women? Balkan Med J 2008;25:105-9.

49. Michaëlsson K, Bergström R, Holmberg L, Mallmin H, Wolk A, Ljunghall $\mathrm{S}$. A high dietary calcium intake is needed for a positive effect on bone density in Swedish postmenopausal women. Osteoporos Int 1997;7:155-61.

50. Sahin Onat Ş, Ünsal Delialioğlu S, Özel S. The relationship between osteoporotic risk factors and bone mineral density. Turk J Osteoporos 2013;19:74-80. 